\title{
Accumbens Homer2 Overexpression Facilitates Alcohol-Induced Neuroplasticity in C57BL/6] Mice
}

\author{
Karen K Szumlinski*,', Alexis W Ary', Kevin D Lominac', Matthias Klugmann² and Tod E Kippin' \\ 'Department of Psychology, Neuroscience Research Institute, University of California at Santa Barbara, Santa Barbara, CA, USA; ${ }^{2}$ Interdisciplinary \\ Center for Neurosciences, University of Heidelberg, Heidelberg, Germany
}

\begin{abstract}
Homer proteins are integral components of the postsynaptic density that are necessary for alcohol-induced neuroplasticity within the nucleus accumbens (NAC). In this report, we describe the effects of chronic alcohol consumption upon NAC Homer expression and investigate the functional consequences of mimicking the alcohol-induced changes in Homer expression vis-à-vis alcohol-induced changes in NAC neurochemistry and behavior. Chronic alcohol consumption under continuous access ( 3 months; daily intake $\approx 11.2 \pm 1.5 \mathrm{~g} / \mathrm{kg} /$ day) produced a robust increase in NAC Homer2 protein levels that was apparent at 2 days, 2 weeks, and 2 months following withdrawal from alcohol drinking. The increased Homer2 expression was accompanied by a less enduring elevation in total $\mathrm{mGluRI}$ and NR2b levels that were evident at 2 days and 2 weeks but not at the 2-month time point. Mimicking the alcohol-induced increase in Homer2 levels by viral transfection of NAC neurons in alcohol-preferring C57BL/6) inbred mice enhanced behavioral output for alcohol reinforcement and increased alcohol intake under both preprandial and postprandial conditions. Moreover, NAC Homer2 overexpression facilitated the expression of an alcohol-conditioned place preference, as well as the development of motor tolerance. Finally, NAC Homer2 overexpression facilitated NAC glutamate and dopamine release following an acute alcohol injection and augmented alcohol-induced dopamine and glutamate sensitization, but did not affect NAC $\gamma$-aminobutyric acid levels. Thus, an upregulation in NAC mGluR-Homer2-N-methyl-D-aspartic acid receptor signaling appears to be an important molecular adaptation to alcohol that promotes neuroplasticity facilitating motivational drive for alcohol and the development of alcoholism-related behaviors. Neuropsychopharmacology (2008) 33, I365-1378; doi:I0.1038/sj.npp. I 30 I473; published online I 3 June 2007
\end{abstract}

Keywords: Homer proteins; ethanol; glutamate receptors; neuroplasticity; glutamate; dopamine

\section{INTRODUCTION}

The transition from recreational alcohol consumption to compulsive drinking (alcoholism) involves neuroadaptations in both pre- and postsynaptic aspects of mesocorticolimbic glutamate transmission (for reviews, see Koob, 2003; Krystal et al, 2003; Siggins et al, 2005), implicating proteins regulating mesocorticolimbic glutamate transmission as molecular candidates in the etiology of addiction. The Homer family of proteins are encoded by 3 genes (Homer1-3) (Soloviev et al, 2000) and act to coordinate synaptic proteins for a variety of cellular functions, including calcium signaling and activity-dependent synaptic remodeling (for reviews, see de Bartolomeis and Iasevoli, 2003; Duncan et al, 2005; Fagni et al, 2002; Xiao et al, 2000). Homer proteins regulate signaling through, and the trafficking of, Group1 metabotropic glutamate receptors

*Correspondence: Dr KK Szumlinski, Department of Psychology, Neuroscience Research Institute, University of California at Santa Barbara, Psychology Building, UCSB, Santa Barbara, CA 93106-9660, USA, Tel: + I 805893 2719, Fax: + I 8058934303 ,

E-mail: szumlinski@psych.ucsb.edu

Received 28 March 2007; revised I 0 May 2007; accepted I I May 2007 and $N$-methyl-D-aspartic acid (NMDA) receptors (eg Naisbitt et al, 1999; Shiraishi et al, 2003; Smothers et al, 2005; Szumlinski et al, 2004, 2005b; Tu et al, 1998, 1999; Xiao et al, 1998). Such regulation is of potential relevance to the neurobiology of alcoholism as these glutamate receptors are two sites of action for alcohol in the brain (eg Lovinger, 1996; Minami et al, 1998). Moreover, in vivo neural genetic studies revealed a critical role for constitutive Homer protein expression in regulating nucleus accumbens (NAC) NMDA, and Group1 mGluR function or expression (Szumlinski et al, 2004, 2005b), maintaining and modulating drug-induced changes in extracellular glutamate levels within the corticoaccumbens pathway (Lominac et al, 2005; Swanson et al, 2001; Szumlinski et al, 2004, 2005a, b, 2006a).

Alternative splicing of the Homer2 generates four gene products (Soloviev et al, 2000), of which, Homer2a and Homer2b are localized in brain (eg Shiraishi et al, 1999). Homer2a/b are structurally and functionally similar proteins that differ from each other by 11 amino acids (Soloviev et al, 2000). Like other constitutively expressed Homer proteins, Homer2a/b contain $\sim 175$ amino-acid residue long regions in their $\mathrm{C}$ termini, which adopt a coiled-coil structure that enables Homer2a/b to multimerize and mediate interactions between their EVH1-bound partners 
(for reviews, see de Bartolomeis and Iasevoli, 2003; Duncan et al, 2005; Fagni et al, 2002; Xiao et al, 2000). Studies of Homer 2 knockout (KO) mice revealed an important role for Homer2 isoforms in regulating alcohol-induced neuroplasticity; KO mice do not develop alcohol-induced dopamine or glutamate sensitization within the NAC and exhibit an alcohol-avoiding and behaviorally intolerant phenotype (Szumlinski et al, 2005b). Viral transfection of NAC neurons with Homer $2 b$ cDNA 'rescues' the alcohol behavioral and neurochemical phenotype of Homer2 $\mathrm{KO}$ mice and shifts the alcohol preference function up and to the left in alcohol-preferring C57BL/6J (B6) inbred mice, supporting an active role for this Homer2 isoform in regulating alcohol-induced neuroplasticity (Szumlinski et al, 2005b). This collection of data has lead to the overarching hypothesis in our laboratory that alcohol-induced changes in NAC Homer expression may be an important mediator of the neuroplasticity relevant to alcoholism.

To test this hypothesis, we first examined the effects of alcohol consumption upon Homer levels in the NAC and then employed behavioral genetic and neurochemical approaches to ascertain the functional consequences of alcohol-mediated changes in NAC Homer expression. As Homer2 proteins regulate the trafficking and expression of Group1 mGluRs and NR2 subunits of the NDMA receptors in vivo (Szumlinski et al, 2004, 2005b), the coregulation of Homers with these proteins was also assessed. Cocaine coregulates the NAC expression of Homer $1 \mathrm{~b} / \mathrm{c}$ and mGluR5 in a time-dependent manner (Swanson et al, 2001). Thus, water- and alcohol-drinking mice were killed at 2 days, 2 weeks, or 2 months withdrawal to examine for the time dependency of alcohol's effects upon protein expression. Our data provide novel evidence that alcohol produces a large and persistent increase in NAC Homer2a/b expression that is accompanied by more transient changes in mGluR1 and NR2b levels. Our earlier behavioral data demonstrated an active and necessary role for NAC Homer2b expression in regulating various aspects of alcohol reward in mice (Szumlinski et al, 2005a). Thus, to determine whether an increase in NAC Homer2b expression is sufficient to alter alcohol-induced neuroplasticity, adeno-associated virus (AAV)-mediated delivery of Homer2b to the NAC of B6 was used to mimic the alcohol-induced rise in Homer2b levels. Our data demonstrate that an upregulation in NAC Homer2b expression promotes alcohol-induced neurochemical plasticity that enhances or facilitates the development of alcoholism-related behaviors.

\section{MATERIALS AND METHODS}

\section{Subjects}

Adult male (8 weeks of age) C57BL/6J (B6) mice were obtained from Jackson Laboratories (Bar Harbor, ME). All mice were individually housed and maintained in polyethylene cages in a colony room, controlled for temperature $\left(25^{\circ} \mathrm{C}\right)$ and humidity $(71 \%)$, under a $12 \mathrm{~h}$ day/12 h night cycle (lights off: 1800). All experimental protocols were consistent with the guidelines of the National Institutes of Health (NIH) Guide for Care and Use of Laboratory Animals (NIH Publication No. 80-23, revised 1996).

\section{Immunoblotting}

B6 mice were permitted 24-h free access to water or alcohol (four bottle choice with $0,3,6$, and $12 \%$ alcohol; Lominac et al, 2006) for a period of 3 months. At 2 days, 2 weeks, and 2 months withdrawal from end of the 3-month period of drinking, the entire NAC (shell and core) was dissected out over ice and homogenized in a medium consisting of radioimmunoprecipitation assay buffer $(65 \mathrm{mM}$ Tris, $150 \mathrm{mM} \mathrm{NaCl}, 1.8 \mathrm{mM}$ Na-deoxycholic acid, $1.3 \mathrm{mM}$ ethylenediaminetetraacetic acid (EDTA), $0.01 \%$ NP-40, $1 \%$ sodium dodecyl sulfate (SDS), Complete Mini-tab Protease Inhibitor Cocktail tablet (Roche Diagnostics GmbH, Mannheim, Germany)). Protein determinations were performed using the BCA Protein Assay Kit (Pierce, Rockford, IL). The procedures employed to quantify Homer $1 \mathrm{~b} / \mathrm{c}$ and Homer2a/ b were identical to those employed previously (Ary et al, 2007), originally adapted from those described in Shin et al (2003) and Swanson et al (2001). Samples $(30 \mu \mathrm{g})$ were subjected to SDS-polyacrylamide gel electrophoresis using Bis-Tris gradient gels (4-12\%) (Invitrogen, Carlsbad, CA) and proteins were transferred to polyvinylidene difluoride membranes, preblocked with phosphate-buffered saline containing $0.1 \%(\mathrm{v} / \mathrm{v})$ Tween 20 and $5 \%(\mathrm{w} / \mathrm{v})$ nonfat dried milk powder for $1 \mathrm{~h}$ before overnight incubation with the following rabbit primary antibodies: anti-Homer $1 \mathrm{~b} / \mathrm{c}$ and anti-Homer2a/b primary antibodies (a generous gift from Dr Paul F Worley, Johns Hopkins University School of Medicine; $1: 1000$ dilution), anti-mGluR1a and anti-mGluR5 (Upstate Cell Signaling Solutions, Lake Placid, NY; 1:1000 dilution), and anti-NR2a and anti-NR2b (Calbiochem, San Diego CA; $1: 1000$ dilution). A rabbit anti-calnexin primary antibody (Stressgen Biotechnologies, Ann Arbor, MI; $1: 1000$ dilution) was used to verify even loading and protein transfer. Membranes were washed, incubated with horseradish peroxidase-conjugated goat anti-rabbit secondary antibody (Upstate; 1:20000-1:40000 dilution) for $90 \mathrm{~min}$, and immunoreactive bands were detected by enhanced chemiluminescence (ECL Plus; Amersham Biosciences Inc., Piscataway, NJ). Immunoreactive levels were quantified by integrating band density $\times$ area using computer-assisted densitometry (Image J, NIH). For each gel, statistical analysis of the density $\times$ area measurements for calnexin failed to detect sample differences (sample effect: $p<0.05$ ), confirming even protein loading and transfer, thus data standardization to the calnexin signal was unnecessary. The density $\times$ area measurements for each Homer and mGluR band were averaged over the saline control samples within a gel and all bands on that gel were normalized as percent of the average control value.

\section{Surgery, Construction, and Infusion of Viral Vectors}

The procedures employed to construct and infuse recombinant adeno-associated virus (rAAV) into the NAC of mice were identical to those described previously in mice (Lominac et al, 2005; Szumlinski et al, 2004, 2005b). Under isoflurane anesthesia, mice were implanted unilaterally with a 26-gauge stainless steel guide cannula ( $20 \mathrm{~mm}$ long) aimed $3 \mathrm{~mm}$ above the NAC (AP: $+0.5 \mathrm{~mm}$; ML: $\pm 0.6 \mathrm{~mm}$; DV: $-2.0 \mathrm{~mm}$, relative to bregma) (Franklin and Paxinos, 1997). Following at least 7 days recovery, AAVs carrying equal 
ratios of AAV1 and AAV2 capsid proteins were used to express either hemagglutinin (HA)-tagged Homer2b or enhanced green fluorescent protein (GFP) under the control of the chicken $\beta$-actin promoter. A total volume of $0.25 \mu \mathrm{l}$ $\left(10^{11}\right.$ viral genomes $\left./ \mathrm{ml}\right)$ was infused unilaterally intra-NAC via injector cannulae (33 gauge, $22 \mathrm{~mm}$ in length; fitted into $20 \mathrm{~mm}$ of 30 -gauge tubing). As in our earlier AAV studies (Klugmann et al, 2005; Lominac et al, 2005; Szumlinski et al, 2004; 2005b; 2006a), a period of 3 weeks was allowed for maximal and persistent transgene expression.

\section{Instrumental Responding for Alcohol}

The apparatus employed to assess instrumental responding for alcohol and alcohol intake under response-contingent conditions consisted of standard mouse operant conditioning chambers (MedAssociates, St Albans, VT) located within ventilated sound-attenuated chambers (Middaugh and Kelley, 1999). The procedures employed to train mice to lever-press for alcohol were similar to those described previously by Middaugh and Kelley (1999). In brief, training sessions were conducted during daily 21-min sessions during the light cycle beginning at 1400 . For these sessions, $12 \%$ ethanol (v/v) was delivered via an infusion pump (MedAssociates) that was connected to a fountain located directly below a nose-poke hole located $15 \mathrm{~cm}$ from the lever. Mice were first trained to press the lever for ethanol delivery $(0.06 \mathrm{ml} /$ infusion) on a fixed ratio 1 (FR1) schedule of reinforcement with a 20 -s timeout period. To expedite the acquisition of self-administration, mice were restricted to $90 \%$ of their ad libitum body weight throughout testing and were tested under postprandial conditions (low hunger/high thirst), $1 \mathrm{~h}$ following the receipt of their daily food ration. Water was available ad libitum with the exception of the $1 \mathrm{~h}$ before self-administration training. Mice continued on the FR1 schedule until a response criterion of 3 consecutive days of greater than 10 reinforced lever presses/session with at least 100 contacts with the ethanol delivery fountain. Once initial self-administration criterion for $12 \%$ alcohol was met on an FR1 schedule, the FR schedule was increased to an FR2. Following stabilization of responding on the FR2 schedule, a dose-response function for alcohol was established by substituting the $12 \%$ alcohol training solution with one of four alcohol concentrations $(0,3,6$, or $12 \% \mathrm{v} / \mathrm{v})$. The order of testing was randomized across AAV treatment groups. Testing occurred every 3-5 days, upon re-establishment of stable responding for $12 \%$ alcohol.

Upon completion of the dose-response function for alcohol self-administration under postprandial conditions, the dose-response function was established under preprandial conditions (high hunger/low thirst) (Middaugh and Kelley, 1999). In this condition, mice were not fluid restricted and received their daily food ration after the selfadministration sessions. Once responding for $12 \%$ alcohol stabilized, the $12 \%$ alcohol training solution was substituted with one of four alcohol concentrations $(0,3,6$, and $12 \%$ $\mathrm{v} / \mathrm{v})$. Again, testing occurred every 3-5 days upon reestablishment of stable responding for $12 \%$ alcohol. At the completion of the preprandial dose-response function, mice were allowed to respond again for $12 \%$ alcohol. Following 3 days of stable responding, blood was sampled from the infraorbital sinus immediately upon completion of the 21-min session. Blood was analyzed for alcohol concentrations using gas chromatography procedures described previously (Middaugh et al, 2003; Szumlinski et al, 2005b).

\section{Alcohol-Conditioned Place Preference}

An unbiased place conditioning procedure was employed using an apparatus with two distinct compartments differing in wall pattern and floor texture and digital video tracking automatically recorded the time spent in each of the two compartments (Stoelting Company, Wood Dale, IL). The procedures to induce an alcohol-conditioned place preference were similar to those described previously for B6 mice (Lominac et al, 2006). To verify that the apparatus was unbiased before conditioning, a preconditioning test was conducted in which mice had free access to both compartments for $15 \mathrm{~min}$. Alcohol-induced place conditioning was produced by eight repeated pairings, on alternating days, of intraperitoneal (i.p.) injections of $2 \mathrm{~g} / \mathrm{kg}$ alcohol with one of the compartments and saline ( $\mathrm{vol}=0.02 \mathrm{ml} / \mathrm{g}$ body weight) with the opposite compartment of the place conditioning apparatus. This alcohol injection regimen was selected as it produces a significant increase in the time spent in the alcohol-conditioned compartment when animals are tested using a biased place-conditioning procedure (Lominac et al, 2006; Szumlinski et al, 2005a). Paired and unpaired compartments were counterbalanced across the groups. A postconditioning test followed the last alcohol conditioning session in which animals again had free access to both compartments. The difference in the amount of time spent in the alcohol-paired $v s$ unpaired environment on the postconditioning test served to index the magnitude of place conditioning.

\section{Tolerance to the Motor-Inhibitory and Sedative Effects of Alcohol}

To assess the effects of NAC Homer2 overexpression upon the acute motor-inhibitory effect of alcohol and the development of tolerance upon repeated alcohol administration, groups of AAV-treated mice were injected repeatedly with either saline or $2 \mathrm{~g} / \mathrm{kg}$ alcohol, every other day, and the locomotor activity of the mice was assessed on injections 1 and 8 of repeated treatment. For this experiment, mice were placed in opaque Plexiglas activity chambers $(23 \times 24 \times 22 \mathrm{~cm})$ equipped with photocells and locomotor activity was monitored for $15 \mathrm{~min}$ following injection.

\section{In Vivo Microdialysis and HPLC for Monoamines and Amino Acids}

To relate the behavioral effects of NAC Homer2 overexpression to alcohol-induced changes in NAC neurochemistry, in vivo microdialysis was performed in groups of AAV-GFP and AAV-Homer2b mice following repeated treatment with either saline or alcohol $(8 \times 2 \mathrm{~g} / \mathrm{kg}$ alcohol, every other day). The procedures for microdialysis probe construction and dialysate collection were identical to those described previously (eg Lominac et al, 2006; Szumlinski et al, 2005b, 2007). A microdialysis probe (24 gauge, $23 \mathrm{~mm}$ in length, including $0.7-1.0 \mathrm{~mm}$ active membrane) was 
inserted unilaterally into the NAC and perfused at a rate of $2.0 \mu \mathrm{l} / \mathrm{min}$ with artificial cerebrospinal fluid. After 3-4 h, when baseline neurotransmitter levels were stable (see Figure 6), baseline dialysate was then collected in 20-min fractions into $10 \mu \mathrm{l}$ of preservative $\left(0.075 \mu \mathrm{M} \mathrm{NaH} \mathrm{N}_{2} \mathrm{PO}\right.$, $25 \mu \mathrm{M}$ EDTA, $0.0017 \mu \mathrm{M}$ 1-octansulfonic acid, $10 \%$ acetonitrile (v/v), $\mathrm{pH}$ 3.0) for $1 \mathrm{~h}$. Two microdialysis sessions were conducted per animal. After $48 \mathrm{~h}$ following the last alcohol/ saline injection, a no net-flux study was conducted in which mice were infused, through the microdialysis probe, with increasing concentrations of glutamate $(0,2.5,5$, and $10 \mu \mathrm{M}$ ) as described previously (Szumlinski et al, 2004, 2005a, 2006a). Three to four days following the no-net flux study, a conventional microdialysis experiment was performed using the opposite side to assess for the effects of AAV infusion upon the neurochemical response to a challenge injection of alcohol. For this experiment, dialysate was collected every $20 \mathrm{~min}$ for $1 \mathrm{~h}$ before, and then for $3 \mathrm{~h}$ following, an i.p. injection of $2 \mathrm{~g} / \mathrm{kg}$ alcohol, in a manner similar to that conducted previously in Homer2 $\mathrm{KO}$ and $\mathrm{B} 6$ mice (Lominac et al, 2006; Szumlinski et al, 2005b, 2007).

The high-pressure liquid chromatography (HPLC) system and the procedures for the electrochemical detection of dopamine, glutamate, and $\gamma$-aminobutyric acid (GABA) in the dialysate of mice were identical to those described previously (Lominac et al, 2006; Szumlinski et al, 2007). The neurotransmitter content in each sample was analyzed by peak height and was compared with external standard curves (one for each neurotransmitter examined) for quantification using ESA Coularray for Windows software.

\section{Verification of AAV Transduction}

Animals were transcardially perfused with phosphatebuffered saline, followed by a $4 \%$ paraformaldehyde solution. Brains were removed and sliced along the coronal plane in $50 \mu \mathrm{m}$ sections at the level of the NAC. AAV transfection was verified by immunostaining for the HA tag and for GFP as described previously (Lominac et al, 2005; Szumlinski et al, 2004, 2005b, 2006a).

\section{Statistical Analyses}

All data were analyzed using analyses of variance (ANOVAs). If significant interactions were found, the data were decomposed for main effects, followed by least significant difference post hoc comparisons.

\section{RESULTS}

\section{Alcohol Consumption Increases Accumbens Homer2 Expression}

Earlier behavioral genetic data supported an important role for Homer2 isoforms in alcohol-induced neuroplasticity (Szumlinski et al, 2005b) and constitutive Homer1b/c protein expression is downregulated in the NAC during withdrawal from repeated cocaine in a time-dependent fashion (Swanson et al, 2001). Accordingly, we examined for the regulation of Homer and glutamate receptor expression during the course of protracted alcohol withdrawal by immunoblotting for the constitutively expressed Homer isoforms Homer1b/c and Homer2a/b, the mGluR1 and mGluR5 subtypes of Group1 mGluRs, as well as the NR2a and NR2b subunits of the NMDA receptor on whole NAC tissue derived from B6 mice. For this, mice were allowed free access to four bottles containing $0,3,6$, and $12 \%$ alcohol for a period of 3 months (Lominac et al, 2006) and then mice were killed at 2 days, 2 weeks, and 2 months after cessation of alcohol drinking ( $n=7-9 /$ time point). As per our earlier study in B6 mice (Lominac et al, 2006), mean daily alcohol intake was consistently high and averaged $11.2 \pm 1.5 \mathrm{~g} / \mathrm{kg} /$ day during the last week of the 3 -month drinking period. The data for immunoblotting for these mice at the various withdrawal time points are presented in Figure 1. Relative to water-drinking controls, chronic alcohol consumption produced a robust, 2.5 -fold, increase in NAC Homer2 levels when assessed at 2 days withdrawal, and the magnitude of this increase was unchanged at 2 weeks and 2 months withdrawal. The rise observed in Homer2 was accompanied by a similar rise in NR2b levels and an approximately 50\% elevation in mGluR1 expression. However, in contrast to Homer2 expression, the alcohol withdrawal-induced elevations in NR2b and mGluR1 levels were no longer apparent at 2 months withdrawal. Alcohol consumption did not consistently affect the expression of Homer1b/c, mGluR5, or NR2a. Thus, withdrawal from chronic alcohol drinking produces an enduring upregulation of the expression of specific components of the mGluR-Homer-NMDA signaling complex and in the case of Homer2, this upregulation persists for up to 2 months following drinking cessation.

\section{Homer2 Overexpression Enhances Instrumental Responding for Alcohol}

Next, we examined the consequences of NAC Homer2 overexpression by assessing for alcohol-induced changes in behavior and neurochemistry in the alcohol-preferring B6 mouse following transfection of NAC neurons with an AAV carrying Homer $2 b$ cDNA (Homer2) or GFP control. As in our earlier AAV studies (Lominac et al, 2005; Szumlinski et al, 2004, 2005b, 2006a), fluorescent immunocytochemical labeling of the HA tag revealed neuronal transfection within the NAC that was restricted to $1-1.5 \mathrm{~mm}$ of the injection site (see Supplementary Information).

To assess the functional importance of the alcohol drinking-induced rise in NAC Homer2 levels vis-à-vis the motivational drive for alcohol, we employed an operant selfadministration paradigm to compare the alcohol doseeffect functions for lever-pressing and intake between B6 mice infused intra-NAC and an AAV carrying GFP or Homer $2 b$. As alcohol consumption depends upon internal drive states, alcohol dose-effect functions were established under both postprandial (high thirst/low hunger) and preprandial (low thirst/high hunger) conditions (Middaugh and Kelley, 1999; Middaugh et al, 1999). The data from this experiment are summarized in Figure 2. NAC Homer2 overexpression in B6 mice increased both appetitive and consummatory aspects of alcohol reinforcement under response-contingent conditions. The effect of Homer2 overexpression was independent of internal drive state, as the increase in lever-pressing for and intake of alcohol was apparent under both pre- and postprandial conditions. 

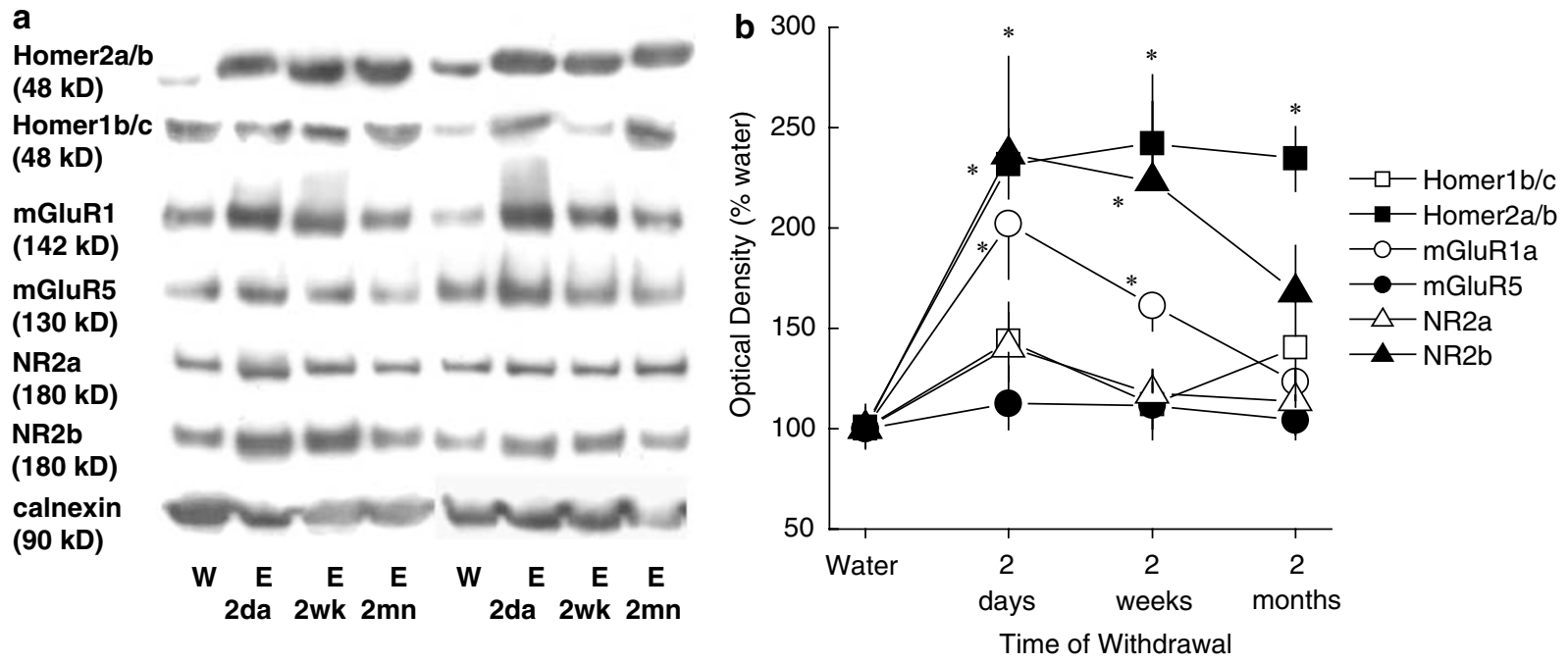

Figure I Chronic voluntary alcohol intake produces enduring Homer2, but transient NR2b and mGluRI, elevations in the NAC. (a) Representative immunoblots for the total protein levels of Homer2a/b, Homer lb/c, NR2a, NR2b, mGluRI, mGluR5, and calnexin (loading control) in the NAC of groups of mice killed at 2 days, 2 weeks, and 2 months withdrawal from 3 months of water $(W)$ or alcohol consumption (mean daily intake $=11.2 \pm 1.5 \mathrm{~g} / \mathrm{kg}$ ). (b) Summary of the change in protein expression following withdrawal from 3 months of continuous alcohol consumption. Compared to water-drinking mice, chronic alcohol consumption elevated NAC Homer2a/b levels at all withdrawal time points $(F(3,33)=\mid 4.0, p<0.000$ I), but did not affect significantly NAC Homerlb/c levels $(p=0.25)$. Alcohol withdrawal did not affect NR2a levels $(p=0.24)$ or the levels of mGluR5 $(p=0.35)$, but elicited a rise in NR2b and mGluRla that persisted for at least 2 weeks (for NR2b: $F(3,34)=2.7, p=0.06$; for mGluRIa: $F(3,34)=8.1$, $p<0.000 I$ ). Data in $(b)$ represent the mean \pm SEM of 7-9 animals/time point. $* p<0.05$ vs water control.

Moreover, the facilitation of instrumental responding and alcohol intake by Homer2 overexpression was observed only during responding for the two highest concentrations tested. Consistent with the large differences in alcohol intake between Homer2- and GFP-infused mice, the blood alcohol levels attained following the last preprandial session in which animals were responding for $12 \%$ alcohol revealed an almost two-fold increase in alcohol concentrations in mice infused with AAV-Homer2 (Homer2: $181.9 \pm 9.3 \mathrm{mg} \%$; GFP: $\left.108.5 \pm 7.1 \mathrm{mg} \% ; t_{25}=6.26, p<0.0001\right)$. Thus, elevating NAC Homer2 levels enhances the reinforcing properties of higher alcohol concentrations in mice genetically predisposed to high alcohol intake.

\section{Homer2 Overexpression Facilitates the Development of} an Alcohol-Induced Place Preference

NAC Homer2 actively regulates the development of an alcohol-conditioned place aversion (Szumlinski et al, 2005b). Given our above data for alcohol reinforcement, we next assessed the effects of NAC Homer2 overexpression upon alcohol-conditioned reward in B6 mice. An unbiased place-conditioning procedure was employed in which $2 \mathrm{~g} / \mathrm{kg}$ alcohol was paired eight times with a distinct compartment of a two-compartment apparatus (Lominac et al, 2006). The data are summarized in Figure 3. Before conditioning, the time spent in the alcohol-paired and alcohol-unpaired sides did not differ for either AAV treatment groups (Side effect: $p=0.68$; AAV $\times$ Side: $p=0.33$; data not shown). While the repeated pairing of $2 \mathrm{~g} / \mathrm{kg}$ alcohol was insufficient to alter the motivational valence of either compartment in GFP controls, AAV-Homer2b mice exhibited a significant increase in the time spent in the alcohol-paired side, relative to the alcohol-unpaired side when the mice were tested in an alcohol-free state. Thus, NAC Homer2 overexpression also facilitates the development of alcoholconditioned reward in B6 mice.

\section{Homer2 Overexpression Facilitates the Development of} Tolerance to Alcohol-Induced Motor Inhibition

NAC Homer2 actively regulates the development of tolerance to the motor-inhibitory effects of higher alcohol doses (Szumlinski et al, 2005b). Thus, we next examined the effects of NAC Homer2 overexpression upon the changes in locomotor activity produced by the repeated administration of $2 \mathrm{~g} / \mathrm{kg}$ alcohol. The data summarizing the effects of NAC Homer2 overexpression upon alcohol-induced locomotion are summarized in Figure 4. Consistent with the findings of earlier AAV studies (Szumlinski et al, 2004, 2005b), an acute injection of $2 \mathrm{~g} / \mathrm{kg}$ alcohol lowered the locomotor activity of AAV-GFP and AAV-Homer2b mice to a similar extent, compared to saline-injected controls (Figure 4a). Thus, NAC Homer2 overexpression did not affect the locomotor inhibition produced by an acute injection of $2 \mathrm{~g} / \mathrm{kg}$ alcohol. However, an examination of the change in locomotion from injection 1 to 8 of repeated treatment revealed a significant increase in the locomotor response to $2 \mathrm{~g} / \mathrm{kg}$ alcohol only in Homer2-infused mice but no group differences were observed for the change in locomotion produced by repeated saline administration (Figure $4 \mathrm{~b}$ ). Thus, NAC Homer2 overexpression facilitated the development of tolerance to the locomotor-inhibitory effects of a moderate dose of alcohol.

Homer2 Overexpression Facilitates the Development of Alcohol-Induced Neurochemical Sensitization

Homer2 expression both maintains NAC basal extracellular glutamate levels (Szumlinski et al, 2004, 2005b, 2006a) and 
Post-prandial
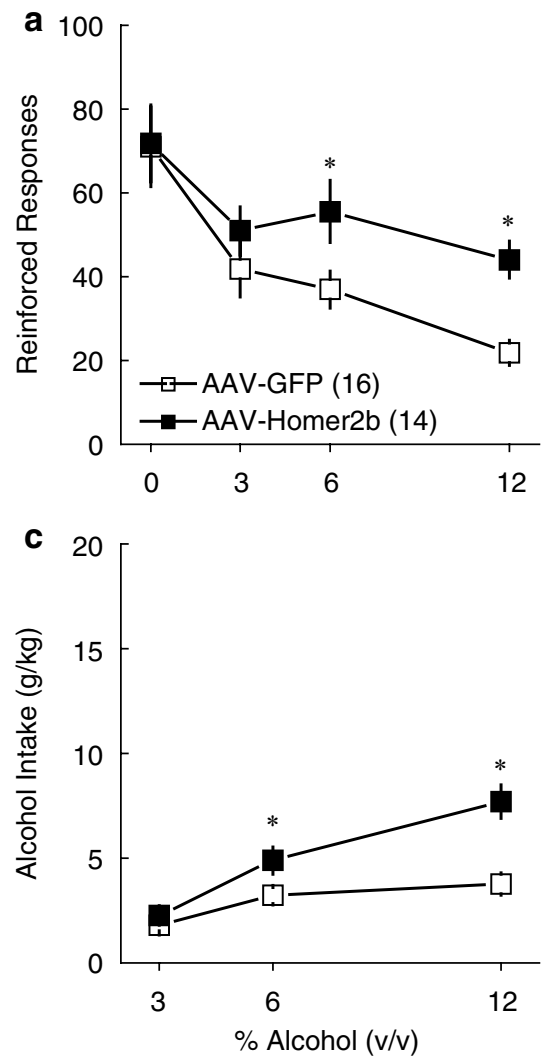
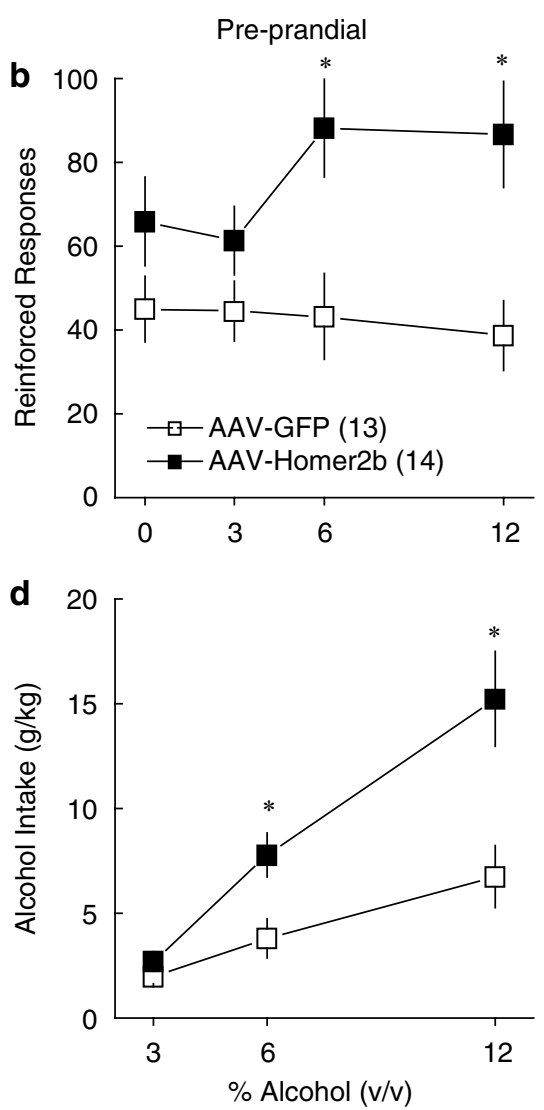

Figure 2 NAC Homer2 overexpression increases appetitive behavior for and the consumption of higher concentrations of alcohol. An intra-NAC infusion of AAV-Homer2b increased both consummatory and appetitive aspects of alcohol reward, independent of internal drive state (for both leverpressing and intake: AAV effect: $p<0.002 ; A A V \times$ Condition: $p>0.05)$. Moreover, the facilitatory effect of Homer2 overexpression was most apparent at the highest alcohol concentrations tested (for both variables: AAV $\times$ Concentration: $p<0.007$; $A A V \times$ Concentration $\times C o n d i t i o n, ~ p>0.05)$. AAVHomer2b infusion increased lever-pressing for alcohol when assessed under both (a) postprandial conditions $(A A V$ effect: $F(I, 28)=4.14, p=0.05)$ and $(b)$ preprandial conditions (Concentration $\times$ AAV: $F(3,75)=2.8, p=0.05$ ). AAV-Homer2b infusion also increased alcohol consumption under both (c) postprandial conditions (Concentration $\times A A V: F(2,56)=12.0, p<0.0000 I$ ) and (d) preprandial conditions (Concentration $\times A A V: F(2,50)=7.6$, $p=0.00 \mathrm{I})$. Data represent the mean \pm SEM of the number of animals indicated in parentheses. $* p<0.05$ vs AAV-GFP.

regulates the increase in extracellular glutamate and dopamine produced by repeated alcohol administration (Szumlinski et al, 2005b). Thus, in vivo microdialysis was conducted in the NAC to assess the neurochemical correlates of the facilitated alcohol-induced behavioral adaptation produced by NAC Homer2 overexpression and these data are summarized in Figure 5 and Table 1. Neither NAC Homer2 overexpression nor repeated alcohol administration $(8 \times 2 \mathrm{~g} / \mathrm{kg}$, i.p., every other day) affected the basal extracellular levels of any of the neurotransmitters examined (Table 1) (no main effects of, or interactions with the AAV factor, $p>0.05$ ). As illustrated in Figure 6, the lack of effects of alcohol and AAV infusion were supported by the results of the no-net flux in vivo microdialysis study, which indicated equivalent basal glutamate content $(y=0)$ and probe recovery (slope of the linear regression plots) between the four treatment groups $(p>0.05)$. NAC Homer2 overexpression facilitated a rise in NAC glutamate following an acute injection of $2 \mathrm{~g} / \mathrm{kg}$ alcohol, which resembled that of repeated alcohol-injected GFP control mice (compare Figure $5 \mathrm{a}$ and $\mathrm{b}$ ). Moreover, NAC Homer2 overexpression augmented the alcohol-sensitized glutamate response in repeated alcohol-injected animals (Figure 5b). While not as robust as the effects upon NAC glutamate, NAC Homer2 overexpression also elicited a moderate rise in NAC dopamine following acute alcohol, which was less robust in GFP controls (Figure 5c) and augmented the alcoholsensitized dopamine response in repeated alcohol-injected mice (Figure 5d). In contrast to both glutamate and dopamine, NAC GABA levels were unaffected by either alcohol administration or AAV infusion (Figures 5e and 6f).

\section{DISCUSSION}

The present report provides the first evidence that chronic alcohol consumption induces a large and persistent increase in NAC Homer2a/b protein expression that was accompanied by an enduring, albeit less persistent, upregulation in mGluR1a and NR2b (Figure 1). Consistent with a critical role for Homer2 isoforms in alcohol-induced neuroplasticity (Szumlinski et al, 2005b), mimicking the alcoholinduced rise in NAC Homer2b expression via virusmediated gene delivery to NAC neurons of C57BL/6J (B6) mice increased both the appetitive and consummatory aspects of alcohol reward (Figures 2 and 3) and facilitated 
the development of tolerance to alcohol's sedative effects following repeated alcohol administration (Figure 4). Alcohol-induced alterations in NAC dopamine and glutamate neurotransmission are highly implicated in the development of alcohol dependence and addiction (for reviews, see Carpenter-Hyland and Chandler, 2007; Chandler, 2003; Chandler et al, 1998; Murphy et al, 2002; Krystal et al, 2003; Koob, 2003; Tupala and Tiihonen, 2004). Consistent with this, the 'proalcoholic' behavioral phenotype induced by NAC Homer2 overexpression was accompanied by an augmentation in the NAC dopamine and glutamate responses to acute and repeated alcohol (Figure 5), but

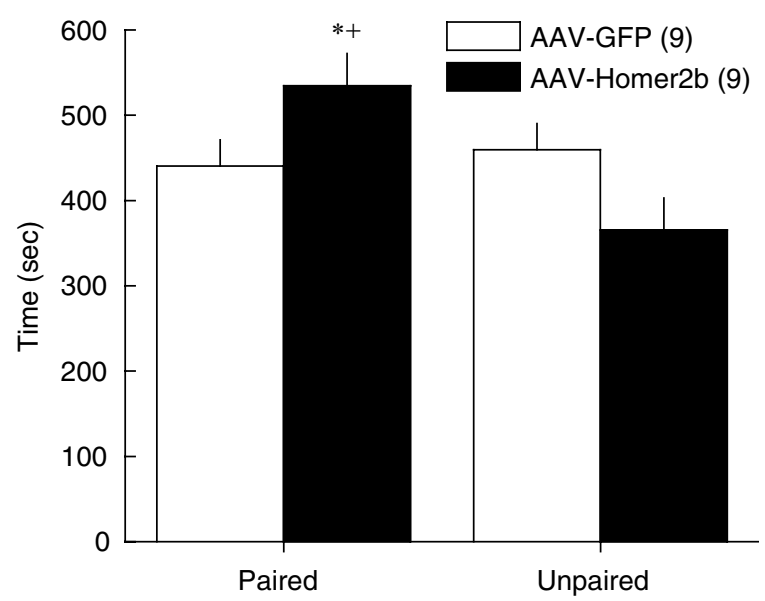

Figure 3 NAC Homer2 overexpression facilitates the development of an alcohol-conditioned place preference. Eight repeated pairings of $2 \mathrm{~g} / \mathrm{kg}$ with a distinct compartment in a two-compartment place-conditioning apparatus resulted in a conditioned place preference in mice overexpressing Homer2b in the NAC, but in GFP controls (Side effect: $F(I, \mid 6)=2.39, \quad p=0.14 ; \quad A A V \times$ Side: $F(I, \mid 6)=3.96, p=0.05)$. Data represent the mean time spent in the alcohol-paired and alcohol-unpaired compartments when the mice were tested in an alcohol-free state \pm SEM of the number of animals indicated in parentheses. $* p<0.05$ vs unpaired side; ${ }^{+} p<0.05$ vs AAV-GFP. no effect upon basal neurotransmitter content (Table 1; Figure 6). Thus, an upregulation in NAC mGluR-Homer2bNMDA signaling is an important cellular adaptation to alcohol that promotes the neuroplasticity underlying motivational drive for alcohol and the development of other alcoholism-related behaviors.

\section{Alcohol Exposure Augments Homer2b and Glutamate Receptor Expression in the NAC}

Alcohol acts as an allosteric inhibitor of a number of glutamate receptors, including NMDA receptors and mGluRs (Lovinger, 1996; Minami et al, 1998). Moreover, the hyperexcitable state observed during early withdrawal from alcohol is attributed to a rebound upregulation in glutamate receptor expression and their trafficking to the postsynaptic density (Carpenter-Hyland and Chandler, 2006; Carpenter-Hyland et al, 2004; Chandler, 2003; Chandler et al, 1999, 2006; Hendricson et al, 2007; Trevisan et al, 1994). Our data are consistent with other reports for alcohol demonstrating an upregulation in the expression of Group1 mGluRs and NMDA receptors during either shortor long-term withdrawal from various alcohol treatment regimens (eg Carpenter-Hyland and Chandler, 2006; Carpenter-Hyland et al, 2004; Chandler et al, 1999; Hendricson et al, 2007; Qiang and Ticku, 2005; Sheela Rani and Ticku, 2006; Simonyi et al, 1996, 2004; Sircar and Sircar, 2006; Trevisan et al, 1994). Moreover, our present data are consistent with the preliminary results of other immunoblotting studies in our laboratory demonstrating an upregulation in NAC Homer2a/b/NR2 expression following repeated bouts of binge alcohol drinking (Szumlinski et al, 2006b) and an injection number-dependent increase in NAC Homer2a/b/Group1 mGluR/NR2 expression at $24 \mathrm{~h}$ following i.p. alcohol injections (Szumlinski, 2006). Further study is required to determine whether the parallel upregulation of Homer2a/b, mGluR1, and NR2b by alcohol results directly from drug-induced inhibition of these receptors. However, in support of this suggestion, the application of the selective NMDA antagonist 2-amino-5-phosphonate
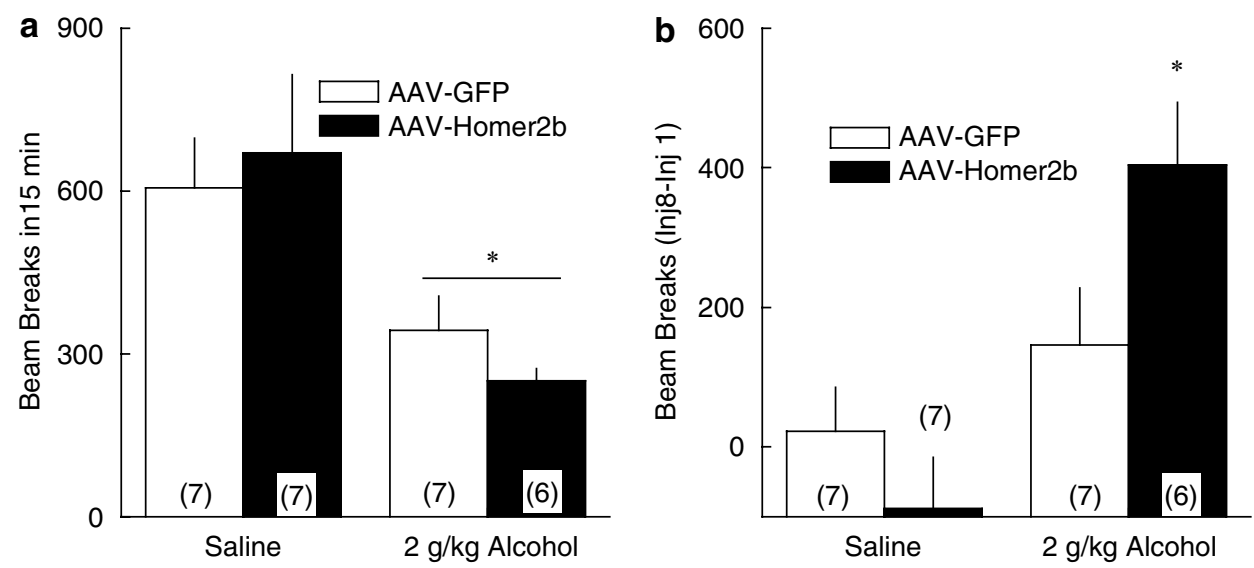

Figure 4 NAC Homer2 overexpression facilitates the development of tolerance to alcohol-induced motor impairment. (a) NAC Homer2 overexpression did not alter the acute locomotor-inhibitory effect of $2 \mathrm{~g} / \mathrm{kg}$ alcohol (Dose effect: $F(I, 26)=\mid 6.44, p<0.000 I$; AAV $\times$ Dose: $p=0.15$ ). (b) NAC Homer2 overexpression facilitated the development of tolerance to alcohol's locomotor-inhibitory effects upon repeated alcohol administration $(8 \times 2 \mathrm{~g} / \mathrm{kg})$ (Dose effect: $F(I, 26)=10.57, p=0.004$; Dose $\times \mathrm{AAV}: F(I, 26)=4.80, p=0.05)$. Data represent the mean $\pm \mathrm{SEM}$ of the number of animals indicated in parentheses. $* p<0.05$ vs saline. 
Acute Alcohol
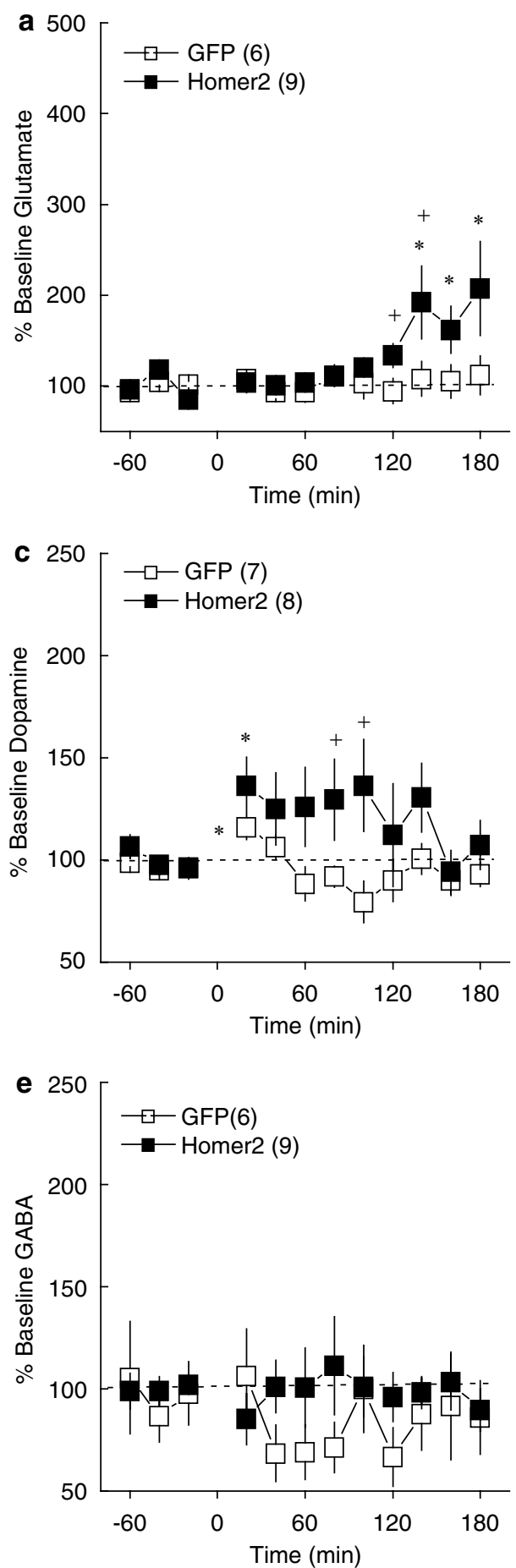

Repeated Alcohol
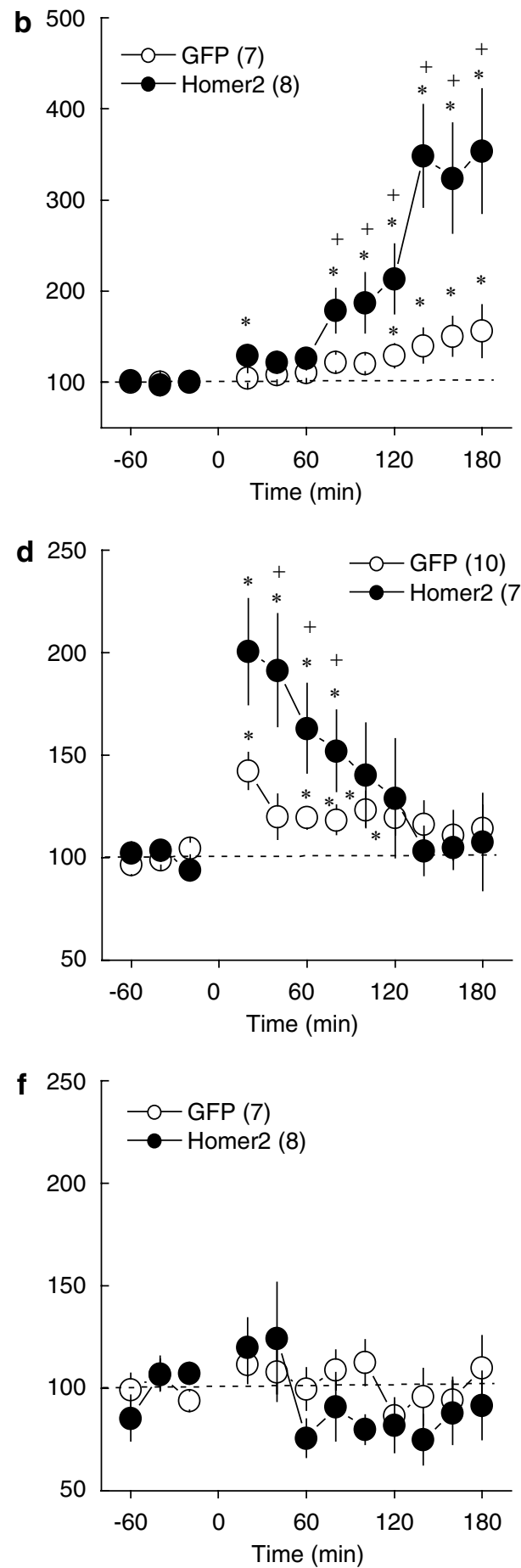

Figure 5 NAC Homer2 overexpression facilitates alcohol-mediated glutamate and dopamine release. (a) An acute injection of $2 \mathrm{~g} / \mathrm{kg}$ alcohol elevated NAC glutamate levels only in mice infused with AAV-Homer2 (AAV $\times$ Time: $F(I|$,$| 43) =1.96, p=0.04$ ). (b) NAC Homer2 overexpression augmented the sensitized glutamate response to alcohol following repeated alcohol treatment $(8 \times 2 \mathrm{~g} / \mathrm{kg})(\mathrm{AAV} \times \mathrm{Time:} F(\mathrm{I}, \mathrm{l}$ 143) $=2.39, p=0.009)$. (c) An acute alcohol injection elicited a slightly larger rise in NAC dopamine levels in mice infused with AAV-Homer2 (AAV $\times$ Time: $F(I I, \mid 43)=2.06, p=0.03)$. (d) NAC Homer2 overexpression augmented the sensitized dopamine response to alcohol following repeated alcohol treatment $(A A V \times$ Time: $F(1$ I, I65) $=1.95$, $p=0.05$ ). (e) and (f) NAC GABA levels were unaffected by either AAV infusion or alcohol administration (three-way ANOVA, $p>0.05$ for all main effects and interactions). The data represent the mean percent change from baseline values per 20 -min fraction \pm SEM of the number of animals indicated in parentheses. ${ }^{*} p<0.05$ vs baseline; ${ }^{+} p<0.05$ vs AAV-GFP.

(AP-V) to developing hippocampal neuronal cultures increases significantly the amount of Homer-glutamate receptor coclustering within the postsynaptic density
(Shiraishi et al, 2003). Thus, glutamate receptor inhibition by alcohol during chronic alcohol consumption may serve as a pharmacological trigger to increase the formation of, 
Table I Comparison of the Average Basal Extracellular Levels of Glutamate, GABA, and Dopamine in the Nucleus Accumbens ( \pm SEM) of AAV-Infused Mice Treated Repeatedly with Saline or $2 \mathrm{~g} / \mathrm{kg}$ Alcohol, as Determined Using Conventional In Vivo Microdialysis Techniques

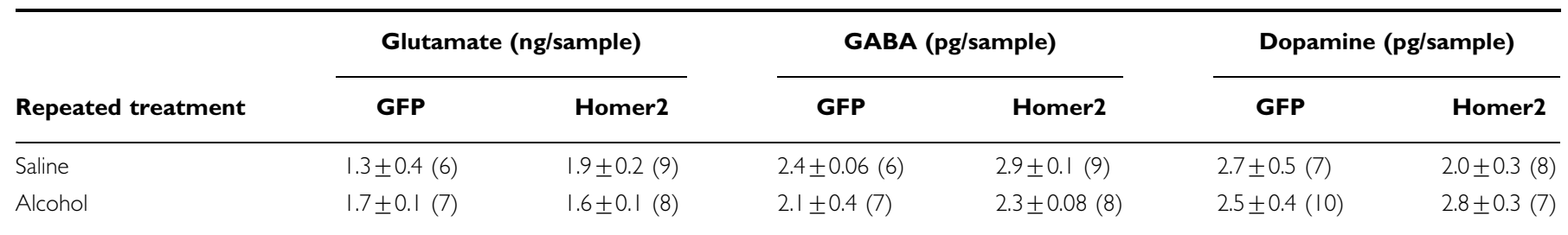

Statistical analysis of the data failed to indicate significant effects of AAV infusion, repeated treatment, or an interaction between these factors ( $p>0.05)$ for any of the neurotransmitters examined. Sample sizes are indicated in parentheses.

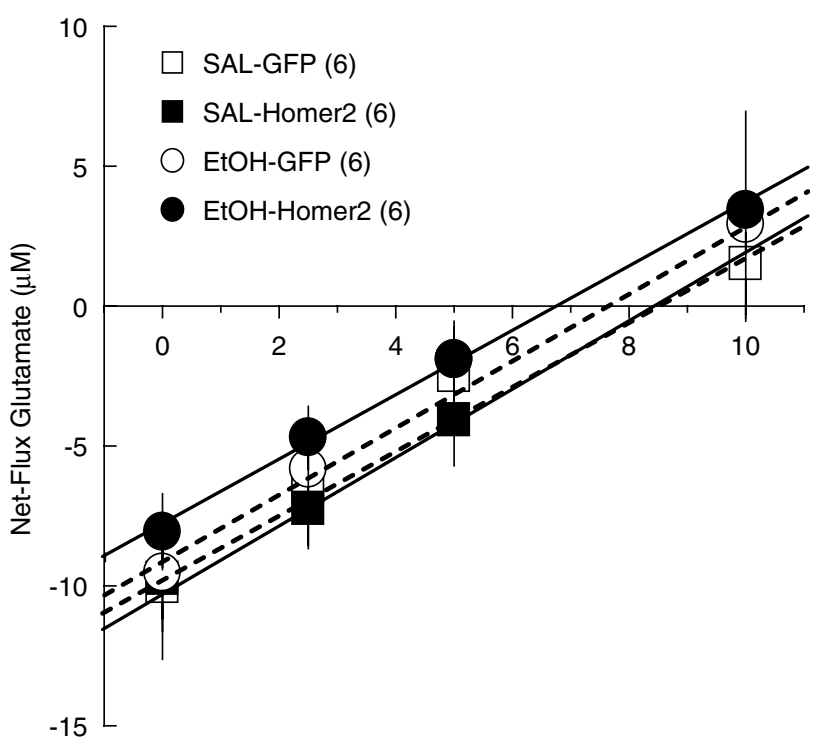

Glutamate $_{\mathrm{IN}}(\mu \mathrm{M})$

Figure 6 NAC Homer2 overexpression or repeated alcohol administration does not alter NAC basal glutamate content. After $48 \mathrm{~h}$ of repeated saline/alcohol administration $(8 \times 2 \mathrm{~g} / \mathrm{kg})$, we failed to detect significant group differences in $y=0$ or for the slopes of the linear regressions of the plots (no main effects of, or interaction between the AAV and EtOH factors, $p>0.05$ ). The data represent the mean \pm SEM of six animals/group.

and signaling through, Homer-containing multiprotein complexes within the postsynaptic density (Chandler et al, 2006; Szumlinski et al, 2006c).

Converging behavioral genetics data derived from both human and animal studies implicate Homer gene products in addiction vulnerability to a variety of substances (for review, see Szumlinski et al, 2006c). Yet, our understanding of how drugs of abuse regulate the expression of different Homer proteins and their interacting partners in brain and the functional consequences of this regulation is very limited. While Homerla mRNA is upregulated within the NAC following acute cocaine (Brakeman et al, 1997), withdrawal from repeated cocaine injections produces a time-dependent downregulation in NAC Homer1b/c and mGluR5 protein expression, that coincides with a reduction in Group1 mGluR function (Swanson et al, 2001). Supporting earlier evidence that Homer gene products regulate the expression of glutamate receptors in vivo (Ghasemzadeh et al, 2003; Szumlinski et al, 2004, 2005b), an alcohol- induced increase in NAC Homer2a/b expression was paralleled by elevations in changes in mGluR1 and NR2b levels. Whether the opposite effects of repeated cocaine and repeated alcohol upon constitutive Homer protein expression are due to pharmacological properties of the drugs or relate to a number of procedural differences between the studies, including the species employed (rat $v s$ mouse), control over drug administration (experimenter-administered $v s$ self-controlled), and the duration and timing of drug exposure (once daily for 1 week $v s$ continuous access for 3 months), cannot be discerned at the present time (Table 2).

\section{Accumbens Homer2b Upregulation Promotes Alcohol Reward}

Converging behavioral genetic and pharmacological evidence implicates signaling through mGluR-Homer-NDMA complexes in the development of alcoholism-related behaviors (Smothers et al, 2005; Szumlinski et al, 2005b, 2006a,b; Urizar et al, 2007; present data). Deletion of Homer2 (Szumlinski et al, 2005b) or pharmacological blockade of either Group1 mGluRs (eg Backstrom et al, 2004; Backstrom and Hyytia, 2007; Hodge et al, 2006; Lominac et al, 2006; Schroeder et al, 2005) or NMDA receptors (eg Boyce-Rustay et al, 2004; for reviews, see Chandler, 2003; Chandler et al, 1998; Hoffman, 2003; Krystal et al, 2003) reduces various aspects of alcohol reward in laboratory animals. Furthering an active and important role for Homer2 proteins in the behavioral effects of alcohol, an intra-NAC infusion of AAV-Homer2b, reverses the alcoholavoiding phenotype of Homer2 $\mathrm{KO}$ mice (Szumlinski et al, 2005b). Moreover, mimicking alcohol's effect upon NAC Homer2a/b expression in $\mathrm{B} 6$ mice via an intra-NAC infusion of AAV-Homer2b shifts the dose-response functions for alcohol preference, for alcohol reinforcement, and for alcohol intake under response-contingent conditions up and to the left of controls (Szumlinski et al, 2005b; present study). These data indicate that NAC Homer2b overexpression is sufficient to increase alcohol's potency and efficacy to elicit reward, a finding supported by our observation that a moderate dose of alcohol elicited a significant conditioned place preference only in mice overexpressing Homer2b (Figure 3). This facilitation of alcohol-induced changes in reward-related behavior is consistent with the results of numerous studies demonstrating an increase in the rewarding or reinforcing effects of alcohol following withdrawal from repeated or chronic 
Table 2 Comparison of the Effects of Manipulating Homer2 Expression upon Measures Related to Alcohol-Induced Neuroplasticity

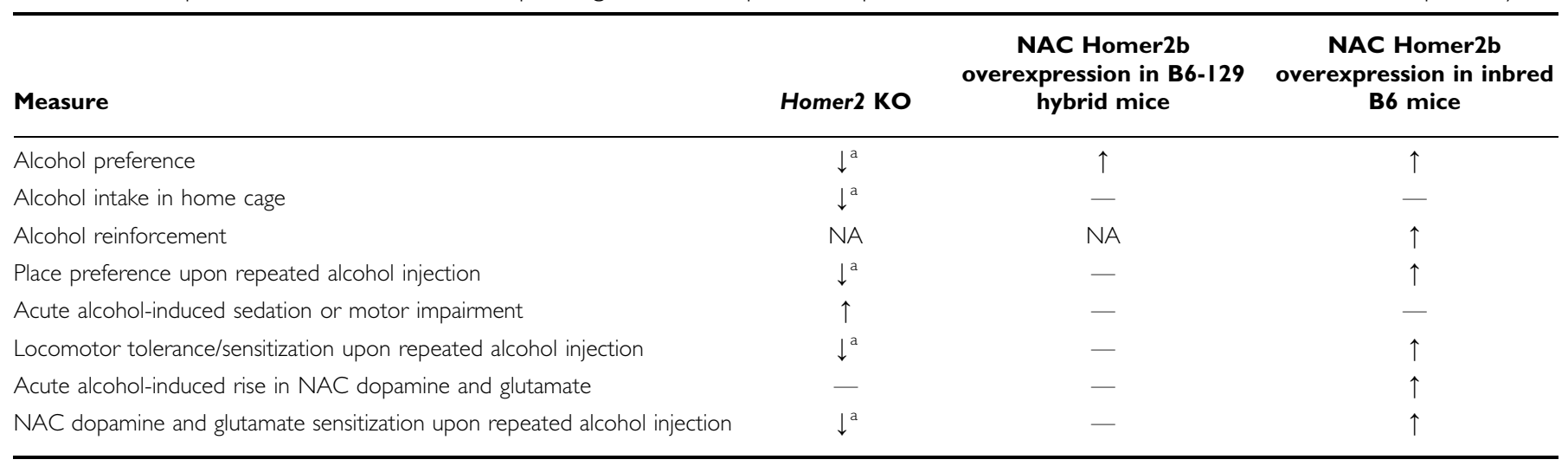

NA, not assessed.

The data provided in this table summarize the results of the present study and those reported in Szumlinski et al (2005b). $\uparrow$ indicates increase relative to control condition; $\downarrow$ indicates decrease relative to control condition; - indicates no difference from control condition.

${ }^{a}$ Reversed by intra-NAC AAV-Homer2b infusion.

alcohol administration (eg Lopez and Becker, 2005; Melendez et al, 2006; Roberts et al, 2000; Valdez et al, 2002; for reviews, Rodd et al, 2004; Spanagel, 2000) and indicate that an alcohol-induced increase in NAC Homer2b expression is sufficient to 'presensitize' B6 mice to alcohol's rewarding and reinforcing properties.

The effects of manipulating Homer expression upon alcohol reward do not likely reflect changes in general reward mechanisms as little evidence supports a role for Homer2 isoforms in regulating food or water reward. Homer2 deletion does not affect sucrose or water reinforcement (Szumlinski et al, 2004; Figure 2), nor does it affect intake of food, body weight regulation, water, or a saccharin solution under response-independent conditions (Szumlinski et al, 2004, 2005b). Homer2 deletion also does not affect the magnitude of a food-conditioned place preference induced under preprandial conditions (Szumlinski et al, 2005a). Thus, while the effects of NAC Homer2b overexpression upon alcohol reinforcement appeared to be greater when the animals were tested under preprandial conditions (Figure 2), this interaction does not appear to depend on direct effects of NAC Homer2b manipulation upon the neural mechanisms mediating homeostatic motivation (ie, food/thirst regulation).

An inverse relationship exists between the rewarding and motor-impairing effects of alcohol in both humans and laboratory animals and the development of tolerance to alcohol's aversive, motor-impairing effects is theorized to underlie enhanced alcohol intake upon repeated alcohol exposure (cf, Gauvin et al, 2000; Schuckit and Smith, 2000; Tabakoff and Hoffman, 1988). Consistent with this theory, the alcohol aversion exhibited by Homer $2 \mathrm{KO}$ mice is accompanied by alcohol-intolerance - a phenotype that can also be 'rescued' by an intra-NAC AAV-Homer2b infusion (Szumlinski et al, 2005b). This latter finding for tolerance in Homer2 KO mice is very much consistent with recent observations that Drosophila with null mutations in $D$. Homer, a gene encoding a single Homer protein that is highly homologous in both structure and function to mammalian Homer1b/c and Homer2a/b proteins (Diagana et al, 2002), exhibits increased sensitivity to the sedative effect of acute alcohol and fails to exhibit rapid tolerance upon a subsequent alcohol exposure (Urizar et al, 2007). Moreover, the alcohol phenotype of D. Homer mutants can be reversed by both pan-neuronal expression of wild-type (WT) Homer and by selective expression of WT Homer within a subset of neurons that include the ellipsoid body (Urizar et al, 2007). Thus, in both mammalian and nonmammalian species, Homers regulate acute behavioral sensitivity to alcohol and are required for the development of tolerance.

Furthering the notion that NAC Homer2b overexpression elicits a behavioral phenotype similar to that produced by repeated alcohol experience (eg Crabbe et al, 1981, 1982; Kalant et al, 1978; LeBlanc et al, 1969; Phillips et al, 1991; Tabakoff and Culp, 1984; Tabakoff et al, 1980), tolerance developed to alcohol's motor-impairing effects following the repeated administration of a moderate dose of alcohol only in mice overexpressing Homer2b (Figure 4). While increases and decreases, respectively in NAC Homer2b overexpression appear to be sufficient to promote and prevent tolerance to alcohol's motor-impairing effects (Szumlinski et al, 2005b; Figure 4), recent evidence implicates both mGluR1 and NMDA receptors in regulating alcohol-induced sedation and motor sensitization (eg Kotlinska et al, 2006; Lominac et al, 2006). While we have yet to assess the effects of an acute bout of alcohol drinking upon mGluR/Homer2/NMDA expression, an acute injection of $3 \mathrm{~g} / \mathrm{kg}$ alcohol is sufficient to elevate NAC Homer2a/b, Group1 mGluR, and NR2 levels (Szumlinski, 2006) and the repeated administration of this dose, which supports place conditioning and induces tolerance to alcohol-induced motor inhibition (eg Lominac et al, 2006; Szumlinski et al, 2005b), enhances alcohol's effect upon Homer2a/b expression. Thus, we propose that a sensitization of signaling through mGluR-Homer-NMDA complexes is a neuroadaptation to alcohol that promotes the development of tolerance and heightens the rewarding properties of this drug. As the effect of chronic alcohol consumption upon mGluR1/Homer2a/b/NR2b expression is enduring (Figure 1), this neuroadaptation may underlie the development of excessive alcohol intake, a defining feature of alcoholism, as well as contribute to the chronic, relapsing nature of this disease. 
Accumbens Homer2b Upregulation Increases NAC Neurochemical Responsiveness to Alcohol

Alcohol consumption, under either continuous or scheduled access conditions, enhances NAC levels of dopamine (eg De Montis et al, 2004; Doyon et al, 2003, 2004, 2006; Gonzales and Weiss, 1998; Melendez et al, 2002; Middaugh et al, 2003; Szumlinski et al, 2007; Weiss et al, 1993) and sensitizes the capacity of alcohol to elevate NAC glutamate (Szumlinski et al, 2007). While neither Homer1 nor Homer2 proteins appear to be necessary for the regulation of NAC basal dopamine content, deletion of Homer1 or Homer2 produces a number of glutamatergic abnormalities within this region that have been implicated in regulating sensitivity to several drugs of abuse (Szumlinski et al, 2006c). Earlier phenotyping of the Homer2 KO mouse revealed a necessary role for Homer 2 gene products in regulating NAC alcohol-induced dopamine and glutamate sensitization (Szumlinski et al, 2005b). Moreover, viral transfection of the NAC with Homer2b rescues the neurochemical hyporesponsiveness of Homer $2 \mathrm{KO}$ mice, demonstrating an active role for this Homer2 gene product in regulating these alcohol-induced neurochemical adaptations within the NAC. Furthering this role, NAC Homer2b overexpression in B6 mice is sufficient to enhance the dopamine and glutamate response to acute alcohol and to augment alcohol-induced neurochemical sensitization (Figure 5). Thus, as observed for behavior, NAC Homer2b overexpression 'presensitizes' the capacity of alcohol to elevate NAC levels of dopamine and glutamate in B6 mice-a neurochemical phenotype akin to that produced by repeated alcohol experience (eg Doyon et al, 2005; Melendez et al, 2002; Middaugh et al, 2003; Szumlinski et al, 2006a, 2007; Weiss et al, 1993; but see Zapata et al, 2006).

Whether the alcohol 'presensitized' neurochemical phenotype produced by NAC Homer2b overexpression relates to an upregulation in mGluR-Homer2-NMDA signaling cannot be discerned from the present study. However, little data exist to support the regulation of alcohol-induced changes in NAC neurotransmitter levels by NMDA receptors (Ericson et al, 2003; Gonzales and Roper, 1993) and both mGluR1 and mGluR5 are necessary for the rise in NAC dopamine and glutamate produced by an acute alcohol injection (Lominac et al, 2006). As Group1 mGluR antagonists are effective at blocking various aspects of alcohol reward in rodents (eg Backstrom et al, 2004; Backstrom and Hyytia, 2007; Hodge et al, 2006; Lominac et al, 2006; McMillen et al, 2005; Olive et al, 2005; Schroeder et al, 2005) and can alter sensitivity to the motor effects of alcohol (Lominac et al, 2006), we propose alcohol-induced increases in Group1 mGluR signaling through Homer2 as a key substrate mediating alcohol-induced neurochemical sensitization within the NAC that underlies the development of alcohol-induced behavioral plasticity relevant to alcoholism.

\section{CONCLUSIONS}

Mounting preclinical evidence indicates members of the Homer protein family of postsynaptic scaffolding proteins as important cellular regulators of vulnerability to addiction-related neuroplasticity within the mesolimbic motive circuit (Szumlinski et al, 2006c). The present study demonstrates that chronic alcohol consumption in alcohol-preferring B6 mice produces a large and persistent increase in Homer2 expression within the NAC that was accompanied by shorter-lasting increases in mGluR1 and NR2b expression. Mimicking the alcohol-induced rise in NAC Homer2 levels enhanced or facilitated behavioral responsiveness to alcohol in a variety of paradigms and augmented the capacity of acute and repeated alcohol to elevate NAC levels of dopamine and glutamate. Thus, an increase in mGluR-Homer2-NMDA signaling may be a cellular adaptation to alcohol that promotes dopamine and glutamate neurotransmission within the NAC and drives a 'proalcoholic' behavioral phenotype.

\section{ACKNOWLEDGEMENTS}

We thank Ms Valerie Aguilar for her technical assistance with the immunostaining. We also thank Dr Paul F Worley and his laboratory (Johns Hopkins University School of Medicine) for the Homer primary antibodies and $\mathrm{Dr}$ Lawrence D Middaugh and his laboratory (Medical University of South Carolina) for the BEL assays. This work was supported by NIAAA Grants AA-015351, AA0135017 (INIA West), and AA-016650 (INIA West) to KKS and by an AMBRF grant to TEK.

\section{DISCLOSURE/CONFLICT OF INTEREST}

There are no conflicts of interest for any of the authors relating to this manuscript. The following organizations have provided compensation over the past 3 years for professional services to:

Karen K Szumlinski, Kevin D Lominac, and Tod E Kippin: Department of Psychology and Neuroscience Research Institute, University of California at Santa Barbara, Department of Neuroscience, Medical University of South Carolina;

Alexis W Ary: Department of Psychology and Neuroscience Research Institute, University of California at Santa Barbara; and

Matthias Klugmann: Interdisciplinary Center for Neurosciences (IZN), University of Heidelberg.

\section{REFERENCES}

Ary AW, Aguilar VR, Szumlinski KK, Kippin TE (2007). Prenatal stress alters limbo-corticostriatal Homer protein expression. Synapse (in press).

Backstrom P, Bachteler D, Koch S, Hyytia P, Spanagel R (2004). mGluR5 antagonist MPEP reduces ethanol-seeking and relapse behavior. Neuropsychopharmacology 29: 921-928.

Backstrom P, Hyytia P (2007). Involvement of AMPA/kainate, NMDA, and mGlu5 receptors in the nucleus accumbens core in cue-induced reinstatement of cocaine seeking in rats. Psychopharmacology [E-pub ahead of print; doi:10.1007/s00213-0070753-8].

Brakeman PR, Lanahan AA, O’Brien R, Roche K, Barnes CA, Huganir RL et al (1997). Homer: a protein that selectively binds metabotropic glutamate receptors. Nature 386: 221-223.

Boyce-Rustay JM, Cunningham CL (2004). The role of NMDA receptor binding sites in ethanol place conditioning. Behav Neurosci 118: 822-834. 
Carpenter-Hyland EP, Chandler LJ (2007). Adaptive plasticity of NMDA receptors and dendritic spines: implications for enhanced vulnerability of the adolescent brain to alcohol addiction. Pharmacol Biochem Behav 86: 200-208.

Carpenter-Hyland EP, Chandler LJ (2006). Homeostatic plasticity during alcohol exposure promotes enlargement of dendritic spines. Eur J Neurosci 24: 3496-3506.

Carpenter-Hyland EP, Woodward JJ, Chandler LJ (2004). Chronic ethanol induces synaptic but not extrasynaptic targeting of NMDA receptors. J Neurosci 24: 7859-7868.

Chandler LJ (2003). Ethanol and brain plasticity: receptors and molecular networks of the postsynaptic density as targets of ethanol. Pharmacol Ther 99: 311-326.

Chandler LJ, Carpenter-Hyland E, Hendricson AW, Maldve RE, Morrisett RA, Zhou FC et al (2006). Structural and functional modifications in glutamateric synapses following prolonged ethanol exposure. Alcohol Clin Exp Res 30: 368-376.

Chandler LJ, Harris RA, Crews FT (1998). Ethanol tolerance and synaptic plasticity. Trends Pharmacol Sci 19: 491-495.

Chandler LJ, Norwood D, Sutton G (1999). Chronic ethanol upregulates NMDA and AMPA, but not kainate receptor subunit proteins in rat primary cortical cultures. Alcohol Clin Exp Res 23: 363-370.

Crabbe JC, Gray DK, Young ER, Janowsky JS, Rigter H (1981). Initial sensitivity and tolerance to ethanol in mice: correlations among open field activity, hypothermia, and loss of righting reflex. Behav Neural Biol 33: 188-203.

Crabbe Jr JC, Johnson NA, Gray DK, Kosobud A, Young ER (1982). Biphasic effects of ethanol on open-field activity: sensitivity and tolerance in $\mathrm{C} 57 \mathrm{BL} / 6 \mathrm{~N}$ and $\mathrm{DBA} / 2 \mathrm{~N}$ mice. J Comp Physiol Psychol 96: 440-451.

de Bartolomeis A, Iasevoli F (2003). The Homer family and the signal transduction system at glutamatergic postsynaptic density: potential role in behavior and pharmacotherapy. Psychopharmacol Bull 37: 51-83.

De Montis MG, Grappi S, Gambarana C, Leggio B, Nanni G, Scheggi S et al (2004). Sardinian alcohol-preferring rats show low 5-HT extraneuronal levels in the MPFC and no habituation in monoaminergic response to repeated ethanol consumption in the NAcS. Brain Res 1006: 18-27.

Diagana TT, Thomas U, Prokopenko SN, Xiao B, Worley PF, Thomas JB (2002). Mutation of Drosophila homer disrupts control of locomotor activity and behavioral plasticity. J Neurosci 22: 428-436.

Doyon WM, Anders SK, Ramachandra VS, Czachowski CL, Gonzales RA (2005). Effect of operant self-administration of $10 \%$ ethanol plus $10 \%$ sucrose on dopamine and ethanol concentrations in the nucleus accumbens. J Neurochem 93: 1469-1481.

Doyon WM, Howard EC, Shippenberg TS, Gonzales RA (2006). Kappa-opioid receptor modulation of accumbal dopamine concentration during operant ethanol self-administration. Neuropharmacology 51: 487-496.

Doyon WM, Ramachandra V, Samson HH, Czachowski CL, Gonzales RA (2004). Accumbal dopamine concentration during operant self-administration of a sucrose or a novel sucrose with ethanol solution. Alcohol 34: 261-271.

Doyon WM, York JL, Diaz LM, Samson HH, Czachowski CL, Gonzales RA (2003). Dopamine activity in the nucleus accumbens during consummatory phases of oral alcohol self-administration. Alcohol Clin Exp Res 27: 1573-1582.

Duncan RS, Hwang SY, Koulen P (2005). Effects of Vesl/ Homer proteins on intracellular signaling. Exp Biol Med 230: 527-535.

Ericson M, Molander A, Lof E, Engel JA, Soderpalm B (2003). Ethanol elevates accumbal dopamine levels via indirect activation of ventral tegmental nicotinic acetylcholine receptors. Eur J Pharmacol 467: 85-93.
Fagni L, Worley PF, Ango F (2002). Homer as both a scaffold and transduction molecule. Sci STKE 137: RE8.

Franklin KBJ, Paxinos G (1997). The Mouse Brain in Stereotaxic Coordinates. Academic Press: San Diego.

Gauvin DV, Baird TJ, Briscoe RJ (2000). Differential development of behavioral tolerance and the subsequent hedonic effects of alcohol in AA and ANA rats. Psychopharmacology 151: 335-343.

Ghasemzadeh MB, Permenter LK, Lake R, Worley PF, Kalivas PW (2003). Homer1 proteins and AMPA receptors modulate cocaine-induced behavioural plasticity. Eur J Neurosci 18: $1645-1651$.

Gonzales RA, Roper LC (1993). Ethanol effects of NMDAstimulated levels of extracellular neurotransmitters by in vivo microdialysis. Alcohol Alcohol Suppl 2: 371-376.

Gonzales RA, Weiss F (1998). Suppression of ethanol-reinforced behavior by naltrexone is associated with attenuation of the ethanol-induced increase in dialysate dopamine levels in the nucleus accumbens. J Neurosci 18: 10663-10671.

Hendricson AW, Maldve RE, Salinas AG, Theile JW, Zhang TA, Diaz LM et al (2007). Aberrant synaptic activation of $N$-methylD-aspartate receptors underlies ethanol withdrawal hyperexcitability. J Pharmacol Exp Ther 321: 60-72.

Hodge CW, Miles MF, Sharko AC, Stevenson RA, Hillmann JR, Lepoutre V et al (2006). The mGluR5 antagonist MPEP selectively inhibits the onset and maintenance of ethanol self-administration in C57BL/6J mice. Psychopharmacology 183: 429-438.

Hoffman PL (2003). NMDA receptors in alcoholism. Int Rev Neurobiol 56: 35-82.

Kalant H, LeBlanc AE, Gibbins RJ, Wilson A (1978). Accelerated development of tolerance during repeated cycles of ethanol exposure. Psychopharmacology 60: 59-65.

Klugmann M, Symes CW, Leichtlein CB, Klaussner BK, Dunning J, Fong D et al (2005). AAV-mediated hippocampal expression of short and long Homer 1 proteins differentially affect cognition and seizure activity in adult rats. Mol Cell Neurosci 28: $347-360$.

Koob GF (2003). Alcoholism: allostasis and beyond. Alcohol Clin Exp Res 27: 232-243.

Kotlinska J, Bochenski M, Danysz W (2006). N-methyl-D-aspartate and group I metabotropic glutamate receptors are involved in the expression of ethanol-induced sensitization in mice. Behav Pharmacol 17: 1-8.

Krystal JH, Petrakis IL, Krupitsky E, Schutz C, Trevisan L, D’Souza DC (2003). NMDA receptor antagonism and the ethanol intoxication signal: from alcoholism risk to pharmacotherapy. Ann NY Acad Sci 1003: 176-184.

LeBlanc AE, Kalant H, Gibbins RJ, Berman ND (1969). Acquisition and loss of tolerance to ethanol by the rat. J Pharmacol Exp Ther 168: 244-250.

Lominac KD, Kapasova Z, Hannun RA, Patterson C, Middaugh LD, Szumlinski KK (2006). Behavioral and neurochemical interactions between Group $1 \mathrm{mGluR}$ antagonists and ethanol: potential insight into their anti-addictive properties. Drug Alcohol Depend 85: $142-156$

Lominac KD, Oleson EB, Pava M, Klugmann M, Schwarz MK, Seeburg PH et al (2005). Distinct roles for different Homer1 isoforms in behaviors and associated prefrontal cortex function. J Neurosci 25: 11586-11594.

Lopez MF, Becker HC (2005). Effect of pattern and number of chronic ethanol exposures on subsequent voluntary ethanol intake in C57BL/6J mice. Psychopharmacology 181: 688-696.

Lovinger DM (1996). Interactions between ethanol and agents that act on the NMDA-type glutamate receptor. Alcohol Clin Exp Res 20(Suppl): 187A-191A.

McMillen BA, Crawford MS, Kulers CM, Williams HL (2005). Effects of a metabotropic, mglu5, glutamate receptor antagonist 
on ethanol consumption by genetic drinking rats. Alcohol Alcohol 40: 494-497.

Melendez RI, Middaugh LD, Kalivas PW (2006). Development of an alcohol deprivation and escalation effect in C57BL/6J mice. Alcohol Clin Exp Res 30: 2017-2025.

Melendez RI, Rodd-Henricks ZA, Engleman EA, Li TK, McBride WJ, Murphy JM (2002). Microdialysis of dopamine in the nucleus accumbens of alcohol-preferring (P) rats during anticipation and operant self-administration of ethanol. Alcohol Clin Exp Res 26: 318-325.

Middaugh LD, Kelley BM (1999). Operant ethanol reward in C57BL/6 mice: influence of gender and procedural variables. Alcohol 17: 185-194.

Middaugh LD, Kelley BM, Cuison Jr ER, Groseclose CH (1999). Naltrexone effects on ethanol reward and discrimination in C57BL/6 mice. Alcohol Clin Exp Res 23: 456-464.

Middaugh LD, Szumlinski KK, van Patten Y, Marlow A-L, Kalivas PW (2003). Chronic ethanol consumption by C57BL/6 mice alters the behavioral and neurochemical effects of ethanol: blockade by naltrexone. Alcohol Clin Exp Res 27: 1892-1900.

Minami K, Gereau IV RW, Minami M, Heinemann SF, Harris RA (1998). Effects of ethanol and anesthetics on type 1 and 5 metabotropic glutamate receptors expressed in Xenopus oocytes. Mol Pharmacol 53: 148-156.

Murphy JM, Stewart RB, Bell RL, Badia-Elder NE, Carr LG, McBride WJ et al (2002). Phenotypic and genotypic characterization of the Indiana University rat lines selectively bred for high and low alcohol preference. Behav Genet 32: 363-388.

Naisbitt S, Kim E, Tu JC, Xiao B, Sala C, Valtschanoff J et al (1999). Shank, a novel family of postsynaptic density proteins that binds to the NMDA receptor/PSD-95/GKAP complex and cortactin. Neuron 23: 569-582.

Olive MF, McGeehan AJ, Kinder JR, McMahon T, Hodge CW, Janak PH et al (2005). The mGluR5 antagonist 6-methyl-2(phenylethynyl)pyridine decreases ethanol consumption via a protein kinase C epsilon-dependent mechanism. Mol Pharmacol 67: 349-355.

Phillips TJ, Burkhart-Kasch S, Crabbe JC (1991). Locomotor activity response to chronic ethanol treatment in selectively bred FAST and SLOW mice. Alcohol Alcohol 1(Suppl): 109-113.

Qiang M, Ticku MK (2005). Role of AP-1 in ethanol-induced $\mathrm{N}$-methyl-D-aspartate receptor $2 \mathrm{~B}$ subunit gene up-regulation in mouse cortical neurons. J Neurochem 95: 1332-1341.

Roberts AJ, Heyser CJ, Cole M, Griffin P, Koob GF (2000). Excessive ethanol drinking following a history of dependence: animal model of allostasis. Neuropsychopharmacology 22: 581-594.

Rodd ZA, Bell RL, Sable HJ, Murphy JM, McBride WJ (2004). Recent advances in animal models of alcohol craving and relapse. Pharmacol Biochem Behav 79: 439-450.

Schroeder JP, Overstreet DH, Hodge CW (2005). The mGluR5 antagonist MPEP decreases operant ethanol self-administration during maintenance and after repeated alcohol deprivations in alcohol-preferring (P) rats. Psychopharmacology 179: 262-270.

Schuckit MA, Smith TL (2000). The relationships of a family history of alcohol dependence, a low level of response to alcohol and six domains of life functioning to the development of alcohol use disorders. J Stud Alcohol 61: 827-835.

Sheela Rani CS, Ticku MK (2006). Comparison of chronic ethanol and chronic intermittent ethanol treatments on the expression of GABA(A) and NMDA receptor subunits. Alcohol 38: 89-97.

Shin DM, Dehoff M, Luo X, Kang SH, Tu J, Nayak SK et al (2003). Homer 2 tunes $\mathrm{G}$ protein-coupled receptors stimulus intensity by regulating RGS proteins and PLCbeta GAP activities. J Cell Biol 162: 293-303.

Shiraishi Y, Mizutani A, Bito H, Fujisawa K, Narumiya S, Mikoshiba K et al (1999). Cupidin, an isoform of Homer/Vesl, interacts with the actin cytoskeleton and activated rho family small GTPases and is expressed in developing mouse cerebellar granule cells. J Neurosci 19: 8389-8400.

Shiraishi Y, Mizutani A, Mikoshiba K, Furuichi T (2003). Coincidence in dendritic clustering and synaptic targeting of homer proteins and NMDA receptor complex proteins NR2B and PSD95 during development of cultured hippocampal neurons. Mol Cell Neurosci 22: 188-201.

Siggins GR, Roberto M, Nie Z (2005). The tipsy terminal: presynaptic effects of ethanol. Pharmacol Ther 107: 80-98.

Simonyi A, Christian MR, Sun AY, Sun GY (2004). Chronic ethanol-induced subtype- and subregion-specific decrease in the mRNA expression of metabotropic glutamate receptors in rat hippocampus. Alcohol Clin Exp Res 28: 1419-1423.

Simonyi A, Zhang JP, Sun AY, Sun GY (1996). Chronic ethanol on mRNA levels of IP3R1, IP3 3-kinase and mGluR1 in mouse Purkinje neurons. Neuroreport 7: 2115-2118.

Sircar R, Sircar D (2006). Repeated ethanol treatment in adolescent rats alters cortical NMDA receptor. Alcohol 39: 51-58.

Smothers CT, Szumlinski KK, Worley PF, Kalivas PW, Woodward JJ (2005). Synaptic function in mice lacking the Homer 2 gene. Alcohol Clin Exp Res 29(Suppl): 141A.

Soloviev MM, Ciruela F, Chan WY, Mcllhinney RA (2000). Mouse brain and muscle tissues constitutively express high levels of Homer proteins. Eur J Biochem 267: 634-639.

Spanagel R (2000). Recent animal models of alcoholism. Alcohol Res Health 24: 124-131.

Swanson C, Baker D, Carson D, Worley P, Kalivas PW (2001). Repeated cocaine administration attenuates group I metabotropic glutamate receptor-mediated glutamate release and behavioral activation: a potential role for Homer $1 \mathrm{~b} / \mathrm{c}$. J Neuroscience 21: 9043-9052.

Szumlinski KK (2006). Up, up and away! facilitation of alcoholinduced neural plasticity by Homer over expression. Alcohol Clin Exp Ther 30(Suppl): 60A.

Szumlinski KK, Abernathy KE, Oleson EB, Klugmann M, Lominac $\mathrm{KD}, \mathrm{He} \mathrm{D}-\mathrm{Y}$ et al (2006a). Homer isoforms differentially regulate cocaine-induced neuroplasticity. Neuropsychopharmacology 31: 768-777.

Szumlinski KK, Dehoff MH, Kang SH, Frys KA, Lominac KD, Rohrer J et al (2004). Homer proteins regulate sensitivity to cocaine. Neuron 43: 401-413.

Szumlinski KK, Diab ME, Friedman R, Henze LM, Lominac KD, Bowers MS (2007). Accumbens neurochemical adaptations produced by binge-like alcohol consumption. Psychopharmacology 190: 415-431.

Szumlinski KK, Friedman J, Rahn A, Cozzoli D, Ary AW (2006b). Excessive alcohol consumption sensitizes glutamate transmission: link to Homer proteins and kinase activation. Neuropsychopharmacology 31: S140.

Szumlinski KK, Kalivas PW, Worley PF (2006c). A possible role of Homer proteins in neuropsychiatric disorders. Curr Opin Neurobiol 16: 251-257.

Szumlinski KK, Lominac KD, Kleschen M, Oleson EB, Dehoff M, Schwartz M et al (2005a). Behavioural and neurochemical phenotyping of Homer1 mutant mice: possible implications for schizophrenia. Genes Brain Behav 4: 273-288.

Szumlinski KK, Lominac KD, Oleson EB, Walker JK, Mason A, Dehoff MH et al (2005b). Homer2 is necessary for ethanolinduced neuroplasticity. J Neurosci 25: 7054-7061.

Tabakoff B, Culp SG (1984). Studies on tolerance development in inbred and heterogeneous stock National Institutes of Health rats. Alcohol Clin Exp Res 8: 495-499.

Tabakoff B, Hoffman PL (1988). Tolerance and the etiology of alcoholism: hypothesis and mechanism. Alcohol Clin Exp Res 12: 184-186.

Tabakoff B, Ritzmann RF, Raju TS, Deitrich RA (1980). Characterization of acute and chronic tolerance in mice selected 
for inherent differences in sensitivity to ethanol. Alcohol Clin Exp Res 4: 70-73.

Trevisan L, Fitzgerald LW, Brose N, Gasic GP, Heinemann SF, Duman RS et al (1994). Chronic ingestion of ethanol upregulates NMDAR1 receptor subunit immunoreactivity in rat hippocampus. J Neurochem 62: 1635-1638.

Tu JC, Xiao B, Naisbitt S, Yuan JP, Petralia RS, Brakeman P et al (1999). Coupling of mGluR/Homer and PSD-95 complexes by the Shank family of postsynaptic density proteins. Neuron 23: 583-592.

Tu JC, Xiao B, Yuan JP, Lanahan AA, Leoffert K, Li M et al (1998). Homer binds a novel proline-rich motif and links group 1 metabotropic glutamate receptors with IP3 receptors. Neuron 21: 717-726.

Tupala E, Tiihonen J (2004). Dopamine and alcoholism: neurobiological basis of ethanol abuse. Prog. Neuropsychopharmacol. Biol Psychiatry 28: 1221-1247.

Urizar NL, Yang Z, Edenberg HJ, Davis RL (2007). Drosophila homer is required in a small set of neurons including the ellipsoid body for normal ethanol sensitivity and tolerance. J Neurosci 27: 4541-4551.
Valdez GR, Roberts AJ, Chan K, Davis H, Brennan M, Zorrilla EP et al (2002). Increased ethanol self-administration and anxietylike behavior during acute ethanol withdrawal and protracted abstinence: regulation by corticotropin-releasing factor. Alcohol Clin Exp Res 26: 1494-1501.

Weiss F, Lorang MT, Bloom FE, Koob GF (1993). Oral alcohol selfadministration stimulates dopamine release in the rat nucleus accumbens: genetic and motivational determinants. J Pharmacol Exp Ther 267: 250-258.

Xiao B, Tu JC, Petralia RS, Yuan JP, Doan A, Breder CD et al (1998). Homer regulates the association of group 1 metabotropic glutamate receptors with multivalent complexes of homerrelated, synaptic proteins. Neuron 21: 707-716.

Xiao B, Tu JC, Worley PF (2000). Homer: a link between neural activity and glutamate receptor function. Curr Opin Neurobiol 10: $370-374$.

Zapata A, Gonzales RA, Shippenberg TS (2006). Repeated ethanol intoxication induces behavioral sensitization in the absence of a sensitized accumbens dopamine response in C57BL/6J and DBA/2J mice. Neuropsychopharmacology 31: 396-405.

Supplementary Information accompanies the paper on the Neuropsychopharmacology website (http://www.nature.com/npp) 